\title{
Stories, movement and country: living and learning together in northern Australia
}

\author{
Matthew Campbell \\ College of Indigenous Futures, Arts \& Society, Charles Darwin University \\ matthew.campbell@cdu.edu.au
}

Keywords: configuration; emergence; home; country; landscape; movement

\begin{abstract}
Using stories to elucidate different ways home might be thought about, this short paper considers the role of 'home' in living with and learning from others to generate a shared sense of belonging in northern Australia, and through that, what lives are able to flourish within it. The paper argues that homes are made collectively, by people, places, and ideas, and perpetuate themselves in the actions that people take. Acting responsibly in making our homes means keeping open the possibility for others to make theirs too, so that we might make homes together. To do this, the paper argues, requires recognising the role of others, human and 'other than human,' in the homes we make and inhabit.
\end{abstract}

\section{Home}

"But this isn't home," my daughter, in tears, slumps into the couch clutching a cushion, the same couch that only days before we were sitting on in a house $1500 \mathrm{~km}$ away.

"I know it doesn't feel like home honey, but it will... in time," I respond, "It's hard, isn't it, to move to a new place." More a statement than a question.

My wife, my son, my daughter and I have just moved to Darwin from Alice Springs, the town in central Australia where both the children were born. For my wife and I it is 'back' to Darwin, as we have lived here before, in this house in fact. It's not my first move, I have moved many times, however the children have not, Alice Springs is where they are from.

This all makes me think what, exactly, is home? A question I'm sure I've asked myself before, but it definitely has a new inflection now. What has more than ten years in Alice Springs, the town in the heart of Australian desert, done to how I think about it?

Perhaps one way to reflect on this is to work through some other versions of what home might mean for some other people, people from the desert. To do this I will generate and/or consider some stories about the Australian desert as a home for people who belong there.

"We grew up on this land, going up and down, walking and on camels. We belong to the Finke and the Palmer [rivers]... We are alright now, and we are not moving from there. That's our land. It was hard going, and we fought for a long time, but we are alright now. We got the land. We know we belong to that land. We lived there, and we grew up there and we are still there today. We are still there nyinanyi ngurangka [staying at home]." Bruce Breaden quoted in 'Every hill got a story.' 
Maantja Tyungurrayi was a Pintupi man who was in his mid-60s when Fred Myers interviewed him as part of his ethnographic research that culminated in the production of his book Pintupi Country, Pintupi Self (Myers, 1986). Myers assembled a (very abbreviated) story of Maantja's life for the book, focusing on a series of events that illustrate his life and which provide insight into how Pintupi lives are animated by place, movement and people. The book itself is one I have come back to over and over during my working life. It provides a compelling insight into the Pintupi in particular, and nomadic Australian Aboriginal life in general. Piquing my interest right now is a small quote from the story. It says "At Piruwatjanya, they encountered three Pitjantjatjarra (sic) men from the south who had seen their fires. These men had gone west for mulyarti wood and were returning" (Myers, 1986,ibid, pp.83-84). This quote is emblematic of much of Maantja's story, in that it tells of Maantja's encounters with various people, not necessarily Pintupi, as they make their way across the country. The implication is that the men were travelling there with permission, so while it was not their country, they were able to travel freely in it provided their intentions were known. In the world that Maantja inhabited asking was expected, with permission rarely withheld. The reason for their travel outside their own country in this example is to enable them to collect prized spear-making wood from trees that do not grow on their country further to the south. In the spirit of openness, they met up with Maantja's group after seeing the smoke from their fires, sharing stories before each went on their way to other places. Movement, country, activity and people figure large in Maantja's story of his childhood. He roamed across vast tracts of what we call the Western Desert, collecting food, meeting up with other people, observing ceremonies; learning the ways of his people which included understanding how the land was a living entity, always animated by those who went before. Maantja, while linked by his birth to a particular place, and to other places by virtue of his parent's affiliations to other places, was nonetheless at 'home' across thousands of square kilometres of country.
"My favourite thing is to play soccer, rugby... I dunno what l'd do without sports...
I do sports every day... I come here and I play... I play outstation and in-station... I play football, rugby, hockey, I do martial arts and boxing, I play soccer..." Young man, interviewed in Alice Springs, January 2018.

"I play outstation and in-station" is the phrase that jumps out to me from this interview conducted with a young central Australian man. The interview took place as part of an evaluation of formalised holiday activities, the funding for which was provided by the Northern Territory Government in proactively attempting to provide things for young people to do in Alice Springs over the 2017/2018 summer school holidays, so that they didn't get up to other things.

In the research, young people attending activities funded through the program were asked about their experience of the program, and about their lives, aspirations and concerns more broadly. The rationale for this approach to the interviews was to open up the possibility that they would not only provide feedback on the programs being delivered specifically, but as well assist with what may be conceived for delivery of this or a similar program in the future insights unavailable to the bureaucrats when they designed the program.

While the target group for the holiday programs were Alice Springs school children, some of those attending, including this young man, would be formally identified as living on an Aboriginal community outside Alice Springs. As he made clear in his interview, such an attribution would misunderstand how he thinks of himself. Rather than being a remote community resident who visits Alice Springs, he is rather someone who is at home in both, fundamentally loosening the tight-knit connection that accompanies the general understanding of home as a specific spatio-temporal location. 
Vanessa is an Aboriginal researcher in the Research Hub of Tangentyere Council in Alice Springs. Tangentyere is an Aboriginal organisation that began its life as a grass roots advocacy organisation campaigning for secure tenure for Aboriginal 'Fringe Camps' but which now provides a diverse range of services to people from across central Australia. In this meeting she is introducing herself to a group of her Tangentyere colleagues in preparation for work we are all going to do together evaluating an innovative alcohol support program run by Tangentyere, known as the Integrated Support Project. She tells them of how she grew up on a cattle station at Hamilton Downs north west of Alice Springs. Her father was a stockman and her mother worked in the homestead. She lived there with her extended family and as a child did not know how to speak English. A couple of times a year she would travel into Alice Springs with her family, the favourite occasion being for the Alice Springs Show. One thing she remembers about these visits was that she was frightened of white people. The family would stay on the north-western outskirts of town, at a place called Nyewente, which is more commonly known as Trucking Yards (or Truckies) owing to its proximity to the parking area for the (long defunct) abattoir.

Her family had negotiated with the central Arrernte Traditional Owners the right to camp there, recognising, appropriately, their authority over that country - their homeland. When she was young their stays there would be brief, returning to the station after a few days or a week. Vanessa explains that she and her family gradually came to spend more and more time in Alice Springs, and at Nyewente in particular, after the Equal Pay Case in the mid-60s (which saw changes to rules which had exempted Aboriginal stockmen from being paid Award wages), again with the blessing of the Traditional Owners. Today Vanessa calls Nyewente her home, noting that she also spends quite a bit of time at Illpye Ilpye camp on the eastern edge of Alice Springs. She also points out that residing in Alice Springs also enables her to more easily travel to her grandmother's country around Titjikala to the south of town.

She goes on to talk about the work she has done at the Tangentyere Council Research Hub, noting with pride the role she has played, and continues to play, in making the stories of people living in Town Camps visible. She sees her connections with the Town Camps and the people that live in them as the foundation for the very possibility of this work. Vanessa, in introducing herself, has introduced her country, including an adopting and adopted homeland, demonstrating the key roles that place, permission, activity and movement play in knowing her - as a person. Her story contains an active place-making theme, showing that the Town Camps are not 'cultural museums', ${ }^{1}$ or places filled with people who belong elsewhere (displaced). Rather they are formed through the ongoing interactions of people, places and the stories that animate them, creating meaningful contemporary people/places which respect the past while nurturing the possibilities of futures built on those pasts.

And so, having moved through these stories, where do I find myself?

One of the things that links these stories, tiny, partial and constructed renderings of aspects of the lives of four desert people, to mine is that they all involve movement. From place to place, yet somehow still being at home. So, what does this assemblage of these stories offer me, and through their juxtaposition, possibly offer you in terms of understanding home? And will it end there, a version of what home might be articulated, and job done?

These stories show that there is more than one way to be at home, and so perhaps paying more attention to how other people are doing their versions of home might help us to understand

1 A characterisation of small Aboriginal settlements made by the then Indigenous Affairs Minister Amanda Vanstone (ABC, 2005) 
our own. It is such a ubiquitous concept, often invoked as a grounding tool, but perhaps not so often thought about, unless it is being taken away, which it has been for many Aboriginal people since the whitefellas (of which I am one) came and said that it was theirs (ours). Terra nullius. More than an academic debate if you are from here.

These stories remind me that we should not think that the story we have of who we are, where we belong, and through them, the meaning of our life, is something that we construct solely in our heads. The stories suggest that mobility and place are active agents in providing shape to our lives - understood as emerging through our relationships with land, with people, and somehow, both of them together as one in the same thing. Now, here in Darwin, a new/old place, and with a child who has never lived here, I'm trying to find something to grasp, trying to find a way to activate the dynamic relation between the old and the new, between this place and that, in order to make a new sense of belonging in this place. Extending this point, if I'm to understand what 'home' means for another, I need to start with my own, mostly banal, experience of being in, moving through, and sitting down in place. And why is this important? Because, as a grounding concept, home and belonging are a central part of making lives with others, something evident within the stories I have assembled.

At a time when climate change is forcing us to recognise our embeddedness in the world - our dependence and our fragility - we are challenged to find ways to deepen our connections with, and take responsibility for, others. We, and the things we share our lives with, are outcomes of the work we do together (and apart), and in making worlds together we also become responsible to each other. While I cannot prescribe that because we emerge together we must act in ways that nurture our collective world, I do concur with Blaser and de la Cadena (2018) that the 'other than humans' that we share our lives with are not just manifestations of cultural belief, they are actors in making worlds, and they live and die in part depending on what we do or don't do. I'm focusing here on concepts and logics; of creation beings and the 'rules' for living they bequeath, which in turn implicates other forms of life.'Rules' for doing the 'right thing' by people and places and things, nurturing relationships, including those we have with those who have gone before us, even if they are no longer with us, all the way back to the ones who brought the knowable world into being. In these terms the 'world' that Maantja lived in no longer exists; there are no Pintupi still walking around the Western Desert like he did. Yet other forms of life which resonate with that kind of life still do, as exemplified by the stories of the young man and Vanessa, albeit somewhat precariously. Some of the 'other than human' actors that configured the life of Maantja still live on in theirs, and indeed mine - including the dynamic interplay between movement and place which have shaped desert life and its notions of home since the knowable world was constructed by the creation beings (and who are still active today).

The stories assembled here, juxtaposed against each other and narrated by me, are intended to show that while we are active in creating our own storylines, we are also configured by things much bigger than us which join us in ongoing becoming. Our very being is generated by people, places, activities and the ideas and concepts that connect us. Activity itself provides a structure through which life takes place, a never-ending process of emergence in which what guides us emerges too.

Working toward understanding ourselves and others as configured - and configured with our homes, concepts and fellow travellers (family and others) - helps us to see our being together in new light. We and the things we live with - humans and 'other than humans' create the world together, agents in an ensemble cast (Pyne Addelson, 1994), going about making the meaningful world. These stories show lives are configured by place, activity and 
movement - lives happen and homes happens in concert, intimately relational. Paying careful attention to how we are configured, and the roles that place, movement and activity play in this configuration, offers the opportunity for doing work that engages differently with the lived realities of the diverse array of people who reside in northern Australia. These stories show that the land is made alive by those who live in it, which confers important responsibility on all of us, but surely a more profound one for those whose connection with this land goes back thousands of generations. Maybe we can still learn together how other lifeways (some stories of which l've assembled here), still here, still alive, despite everything, might be better nurtured. Sadly, such lifeways have too often in the past, and too often in the present, been neglected. These lifeways, so vital and so grounded in this country, remain at risk of being deemed (though, of course, not for those who live them) "unreal, and thus destined for extinction" (de la Cadena and Blaser, 2018, p.13). Our actions, recognising our own embeddedness in this amazing country, should seek to celebrate and centre these worlds in our own, knowing that they generate opportunities for diverse forms of life, and all that depends on them, to flourish anew. And if we can do that, as an act of faith and not a guarantee, then we stand a chance of keeping our mutual home alive.

"We will feel at home here, I promise, and I will do what I can to help make it happen", knowing that it is time, activity and the connections that grow through them, that will create this feeling. A process that can't be rushed.

\section{References}

ABC. (2005). "Vanstone questions future of Indigenous 'cultural museums'." 2019, from https://www.abc.net.au/news/2005-12-09/vanstone-questions-future-of-indigenous-cultural/757866

Bowman, M. (2015). Every hill got a story: We grew up in country. Richmond: Hardie Grant Books. de la Cadena, M. and Blaser, M. (2018). A world of many worlds. Durham: Duke University Press.

Myers, F. (1986). Pintupi Country, Pintupi Self: Sentiment Place and Politics among Western Desert Aborigines. California: University of California Press.

Pyne Addelson, K. (1994). Moral passages: Toward a collectivist moral theory. New York: Routledge. 